\title{
MIMR STIMULATION OF DAIRY MILK ON ACTIVE MANAGEMENT KALA III ON TIME OF PLACENTA DISPOSAL
}

\author{
Aries Abiyoga ${ }^{1 *}$, Tuti Meihartati ${ }^{2}$ \\ ${ }^{1}$ Institute of health technology and science Wiyata Husada Samarinda, Kalimantan Timur, Indonesia \\ ${ }^{2}$ Program Nursing and Midwifery Institute of health technology and science Wiyata Husada \\ Samarinda, Indonesia \\ *Corresponding Author's Email: ariesabiyoga@rocketmail.com
}

\begin{abstract}
Introduction: Actually, more than $90 \%$ of postpartum hemorrhage cases occurring within 24 hours after delivery are caused by uterine atony, one of the factors causing uterine atony due to errors in active management of the third phase such as inappropriate oxytocin administration time. Stimulation of nipple can produce oxytocin naturally and this oxytocin can shorten the time of placental release. This study aims to determine the influence of nipple stimulation on the active management of phase III to the placenta release time. Methods: The method in this study was quasi experimental with post test design only non equivalent control group. Samples in this study were 32 physiological maternal with phase III who were divided into two groups with non probability sampling technique with purposive sampling type. Results: The results in this study, there was a difference in placental release time, in the release intervention placental group faster than the control group and the result was $\rho$ value $<0,001(<0,05)$. Conclusions: there is an effect of mother's nipple stimulation on the active management of phase III to the time of placental release.
\end{abstract}

\section{Keywords: Nipple Stimulation, Placental Release Time}

\section{INTRODUCTION}

Nipple stimulation is a technique that can encourage an initial contraction by doing circular motions, rubbing or gentle massage on the area around the nipple. Nipple stimulation can make the breast stimulated and when the breast is stimulated, the hormone oxytocin will be released which will eventually cause uterine contractions. The uterine contractions that do not contract adequately during labor can be the cause of the old partus, uterine atony and placental retention, both of which are a major cause of postpartum hemorrhage (Bobak, 2005 and Anggraeni \& Hidayah, 2012). According to WHO, every year some 358,000 mothers die at delivery where 355,000 (99\%) are from developing countries. MMR in developing countries is highest with 290 maternal deaths per 100,000 live births when compared with MMR in developed countries ie 14 maternal deaths per 100,000 live births. AKI in 2015 in the world that is 303,000 decreased about $44 \%$ compared with the year 2010 as much as 536.000. Data from the World Health Organization (WHO) states that MMR in developing countries that are bleeding annually is approximately $70 \%(212,100)$ (WHO, 2015).
Based on data obtained in Southeast Asia (ASEAN), as many as 232,000 mothers die each year due to maternal complications, meaning that there is 1 maternal death every 2.3 minutes. The seven factors of maternal death in Asia include; $31 \%$ of deaths due to bleeding, ectopic pregnancy and other complications $15 \%$, anemia $13 \%$, hypertension in pregnancy $9 \%$, obstructive birth, $6 \%$ abortion and infection 12\% (Depkes RI, 2014).

Based on the results of Indonesia Demographic Health Survey in 2012, maternal mortality in Indonesia recorded a significant increase of about 359 / 100,000 live births. This number has increased when compared with the SDKI in 2007, where the AKI about 228 / 100,000 live births. Many factors of maternal mortality include postpartum hemorrhage of about $26.9 \%$, eclampsia at childbirth $23 \%$, infection $11 \%$, puerpurium $8 \%$ complication, $5 \%$ obstetric trauma, $8 \%$ abortion and indirect cause 10.9\% (Depkes RI, 2012).

The global fifth MDGs target is to reduce AKI to 102 / 100,000 live births by 2015. Based on the data SDKI during the period 1991 - 2007, the AKI decreased from 390 / 100,000 to 228 / 100,000 live births. But based on data SDKI in 2012, AKI again rose to 359 / 100,000 live 
births, the number is further away from the target MDGs in 2015 of 102 / 100,000 live births and target of SDGs is 70 / 100,000 live births (Depkes RI, 2012).

Based on data obtained in the province of South Kalimantan, AKI in 2013 is still quite high. Twelve cases were caused by 5 cases of bleeding, 4 cases of eclampsia, 1 infection and 2 other causes, the main cause of maternal mortality due to haemorrhage was placental retention and uterine atony not treated promptly (Depkes Prov Kalsel, 2013).

Based on data obtained in Tanah Bumbu District, the number of maternity mothers in 2016 assisted by health workers as much as $5753(75.4 \%)$ people. The data were taken based on data from Puskesmas in Tanah Bumbu District(Dinkes Kab Tanah Bumbu, 2016).

Based on the preliminary study at RSIA Paradise in 2015 there were 286 mothers, mothers with bleeding were $39(13.6 \%)$ mothers. In 2016 there was an increase of 395 maternal physiologic mothers and maternal mothers with bleeding was $61(15.5 \%)$ of mothers. The main causes of bleeding cases that occur are placental retention and uterine atony (Paradise Hospital, 2016).

More than $90 \%$ of all postpartum hemorrhage cases occurring within 24 hours after childbirth are caused by uterine atony. A uterine atonia occurs due to errors in the third stage of active management such as inappropriate timing of oxytocin, inadequate fundus of uterine and inadequately controlled umbilical cord control. Therefore, active management of the third stage plays a very important role that can prevent the occurrence of bleeding (Jannah, 2015:145-148).

To prevent the occurrence of bleeding either at the time of birth or at the time of post partum, it is very important to do active management at the third stage. Active management of the third stage can shorten the time of birth of the placenta, reduce the incidence of postpartum hemorrhage, and can prevent the occurrence of uterine atony and retention of the placenta (Sumarah, Widyastuti \& Wiyati, 2009:147).

The third stage of active management performed at the time of delivery has several advantages, one of which as mentioned above is that it can shorten the time of birth of the placenta. The birth of the placenta is strongly affected by uterine contractions. The non-contracting uterus can cause longer placental delivery time. To prevent this, when the active management of the third stage is given oxytocin to produce adequate uterine contractions (Eniyati \& Putri, 2012:94-99).

Oxytocin plays an important role in the delivery and delivery of breast milk. Oxytocin is synthesized in the hypothalamus, gonadal glands, placenta and uterus. Oxytocin acts on oxytocic receptors capable of causing uterine contractions that occur through smooth muscle or through increased production of prostaglandins that serve to strengthen uterine contractions. In women, the hormone oxytocin produced by the hypothalamus is released mainly after the widening of the cervix and vagina. Oxytocin serves to facilitate childbirth in the second and third stage and after the stimulus of the nipple. Nipple stimulation can produce oxytocin naturally and this oxytocin will cause the uterus to contract and can shorten the time of placental release (Manuaba, 2008, dalam Yunita, 2010).

Based on the above background and preliminary studies that researchers conducted at the Paradise Hospital, there was an increase in bleeding cases caused by placental retention and uterine atony in 2016 of $15.5 \%$ of maternity mothers. In addition, this research has not been conducted in Tanah Bumbu Regency, especially in the Paradise Hospital of Tanah Bumbu Regency, so the researcher is interested to conduct a research entitled "The Effect of Nipple Stimulation on Active Management Kala III On Time of Release of Placenta at Paradise Hospital of Tanah Bumbu Regency".

\section{METHODOLOGY}

The place of study was conducted at the Paradise Hospital of Tanah Bumbu Regency. The research process begins with the initial data retrieval conducted in March and continued with research conducted in June to July 2017. The design in this study is Quasi Experiment with the design used Post Test Only Non Equivalent Control Group. The population in this study were 129 physiological maternal wives with third stage in June to July at Paradise Hospital of Tanah Bumbu Regency in 2017. The sample used in this study were 32 respondentsdividedintotwogroups, 16 respondents for the intervention group and 16 respondents for the control group conducted by purposive sampling by 
determining the sample according to the inclusion criteria and exclusion criteria.

The instruments for the independent variables (nipple stimulation) used in this study were observation sheets and for the dependent variable (time of placental release) using the observation sheet. The research analysis consisted of univariate and bivariate analysis, to test the hypothesis using non parametric statistic test using Mann Whitney test.

\section{RESULTS}

Table 1: Time Frequency Distribution of Placental Release on Intervention Groups Provided Treatment of Stimulation of Milk and Unwanted Milk Treatment of Nipple Stimulation Milk at Physiological Maternal Wife with Third III at Paradise Hospital of Tanah Bumbu Regency

\begin{tabular}{|l|c|c|}
\hline \multirow{2}{*}{ No } & \multicolumn{2}{|c|}{ Placental Release Time (Seconds) } \\
\cline { 2 - 3 } & $\begin{array}{c}\text { Performed Stimulation } \\
\text { of Milk Putting }\end{array}$ & $\begin{array}{c}\text { No Milk Stimulation } \\
\text { Performs }\end{array}$ \\
\hline $\mathbf{1 .}$ & 260 & 975 \\
\hline $\mathbf{2 .}$ & 380 & 495 \\
\hline $\mathbf{3 .}$ & 240 & 990 \\
\hline $\mathbf{4 .}$ & 310 & 1035 \\
\hline $\mathbf{5 .}$ & 360 & 1010 \\
\hline $\mathbf{6 .}$ & 970 & 440 \\
\hline $\mathbf{7 .}$ & 230 & 1020 \\
\hline $\mathbf{8 .}$ & 435 & 500 \\
\hline $\mathbf{9 .}$ & 925 & 960 \\
\hline $\mathbf{1 0 .}$ & 320 & 1015 \\
\hline $\mathbf{1 1 .}$ & 980 & 490 \\
\hline $\mathbf{1 2 .}$ & 370 & 1030 \\
\hline $\mathbf{1 3 .}$ & 270 & 1095 \\
\hline $\mathbf{1 4 .}$ & 290 & 1150 \\
\hline $\mathbf{1 5 .}$ & 985 & 1000 \\
\hline $\mathbf{1 6 .}$ & 365 & 570 \\
\hline $\begin{array}{l}\text { Rata- } \\
\text { rata }\end{array}$ & 443 & 860 \\
\hline Data recam & & \\
\hline
\end{tabular}

Berdasarkan table 1 it is known that the respondent group given nipple stimulation treatment experienced faster placental release with an average time of placental release of 443 seconds compared with the group of respondents who were given no nipple stimulation treatment with an average time of placental release of 860 seconds.

Table 2: Analysis of Research Results Effect of Nipple Stimulation on Active Management Kala III Against Time Release of Placenta at Hospital Paradise Regency of Tanah Bumbu

\begin{tabular}{|l|l|l|l|l|l|}
\hline No & $\begin{array}{l}\text { Nipple } \\
\text { Stimulation }\end{array}$ & $\begin{array}{l}\text { Mean Value } \\
\text { Placental } \\
\text { Release Time }\end{array}$ & Total & $\mathbf{( \% )}$ & $\begin{array}{l}\boldsymbol{\rho} \text { - } \\
\text { value }\end{array}$ \\
\cline { 1 - 4 } 1. & Do & 9,75 & 16 & 100 & $<0,001$ \\
\cline { 1 - 4 } 2. & Are not Done & 23,25 & 16 & 100 & \\
\hline
\end{tabular}

* Data analysis using non-parametric Spearman rho rank test.

Berdasarkan table 2 it was found that mean of respondent group given nipple stimulation treatment was smaller $(9,75)$ compared with group of respondents who were not given treatment of nipple stimulation with mean value $(23,25)$.

The test used was Mann Whitney test showed that the value of $\rho$ value $<0.001(<0.05)$ means that there is a difference in the time of placental release in the intervention group given the nipple stimulation treatment with the control group that is not given the nipple stimulation treatment in the physiological maternal mother III. Therefore H1 is accepted and H0 is rejected which means there is influence of nipple stimulation on the third stage active management to the time of placenta release.

\section{DISCUSSION}

Berdasarkan hasil penelitian pada tabel 1 in the Paradise Hospital of Tanah Bumbu Regency it was found that the respondent group given the nipple stimulation treatment experienced a faster placental release with an average time of placental release of 443 seconds compared with the respondent group who were not given the nipple stimulation treatment with an average time of placental release of 860 seconds .

The third stage of labor is also called the uri or when the placenta spends. The third stage of labor is a continuation of the first stage (opening time) and second stage (when the infant is released) in labor (Asrinah, Putri, Sulistyorini, Muflihah \& Sari, 2010:101). 
In the third stage, the uterine muscle (myometrium) contracts by decreasing the volume of the uterine cavity after the birth of the baby. Depreciation of this size causes a decrease in the size of the placental attachment site. As the attachment places smaller, while the size of the placenta remains unchanged, the placenta will be folded, thickened, then loose from the uterine wall. Once released, the placenta will descend to the bottom of the uterus or into the vagina (Asrinah, Putri, Sulistyorini, Muflihah \& Sari, 2010:102).

The timing of placental release is affected by several factors including uterine abnormalities such as weakness and ineffectiveness of uterine contractions and tetanic uterine contractions, placental abnormalities such as placenta previa and placenta accreta, and occurrence of errors in the third stage of active management, such as inappropriate timing of oxytocin , inadequate fundus of uterine and inadequately controlled umbilical cord control (Jannah, 2015:145148).

Nipple stimulation is a technique that can encourage an initial contraction by doing a circular motion, rubbing or gentle massage on the area around the nipple of the breast (Bobak, 2005 and dalam Anggraeni \& Hidayah, 2012).

According to the researchers, the group of respondents who were given the treatment of nipple stimulation mostly experienced faster placental release time than the group of respondents who were not given the treatment of nipple stimulation mostly experienced a slower release time of the placenta. This is in accordance with the theory that the stimulation of the nipple will stimulate the body to produce more oxytocin. Oxytocin plays an important role in labor and breastfeeding. Oxytocin is synthesized in the hypothalamus, gonadal glands, placenta and uterus. Oxytocin acts on oxytocic receptors capable of causing uterine contractions that occur through smooth muscle or through increased production of prostaglandins that serve to strengthen uterine contractions. In women, the hormone oxytocin produced by the hypothalamus is released mainly after the widening of the cervix and vagina. Oxytocin serves to facilitate childbirth in the second and third stage and after the stimulus of the nipple. Nipple stimulation can produce oxytocin naturally and this oxytocin will cause the uterus to contract and can shorten the time of placental release (Manuaba, 2008, dalam Yunita, 2010).

\section{CONCLUSION}

There is an effect of nipple stimulation on the active management of the third stage of the placental release time.

\section{Conflict of interest}

The authors declare that they have no conflict of interest.

\section{ACKNOWLEDGEMENT}

The author would like to thank all the staff Mother and Child's Paradise Hospital and Campus College of Health Sciences Darul Azhar Batulicin, Indonesia

\section{REFERENCES}

Abedi, P., Jahanfar, S., Namvar, F., Lee, J. (2016). Breastfeeding or nipple stimulation for reducing postpartum haemorrhage in the third stage of labour. Accessed on 28 Maret2017, dari https:// www.ncbi.nlm.nih.gov/pubmed.

Ariani, A.P. (2014). Application of research methodology of obstetrics and reproductive health. Yogyakarta: Nuha Medika. 116-119

Arikunto, S. (2010). Research procedure. Jakarta: PT Rineka Cipta.61-70

Asrinah., Putri, S.S., Sulistyorini, D., Muflihah, I.S. \& Sari, D.N. (2010). Asuhan kebidanan masa persalinan. Yogyakarta: Graha Ilmu.43-50

Demirel, G. \& Guler, H. (2015). The effect of uterine and nipple stimulation on induction with oxytocin and the labor process. Accessed on 28 Maret 2017, dari https://www.ncbi.nlm.nih.gov/pubmed.

Dharma, K.K. (2011). Methodology of nursing research. Jakarta: Trans Info Media.71-79

District Health Office Tanah Bumbu. (2016). Health profile of Tanah Bumbu Regency in 2016. Tanah Bumbu

Eniyati. \& Putri, M. (2012). Midwifery care of the delivery mother. Yogyakarta: Pustaka Belajar.5558 
Health Department of South Kalimantan Province. (2013). Health profile of South Kalimantan Province in 2013. Banjarmasin: Ministry of Health of South Kalimantan Province.

Ministry of Health of the Republic of Indonesia. (2014). Health demographic survey Indonesia tahun 2012. Jakarta:

Jannah, N. (2015). Midwifery care II: Competencebased delivery.Jakarta: EGC.

Mardalis. (2010). The method of research is a proposal approach. Jakarta: PT Bumi Aksara.219-234

Narasimhulu, D.M., \& Zhu, L. (2015). Uterine tachysystole with prolonged deceleration following nipple stimulationfor labor augmentation.

Nurasiah, A., Rukmawati, A., Badriah, D.L. (2012). Maternity care is normal for the midwife. Bandung: PT RefikaAditama.118-120

Prawirohardjo, S. (2012). Obstetrics. Jakarta: Yayasan Bina Pustaka Sarwono Prawirohardjo.120-222

Paradise Hospital. (2016). Data year physiological birth rate 2016. Tanah Bumbu: Paradise Hospital

Saryono. (2011). Health research methodology. Yogyakarta: Mitra Cendikia Press.291-238

Saryono. \& Anggraeni, M.D. (2013). Qualitative and quantitative research methodology in health. Yogyakarta: Nuha Medika.117-119

Setiawan, A. \& Saryono. (2010). Methodology of obstetrics research DIII, DIV, S1 dan S2. Yogyakarta: Nuha Medika.281-299

Sulistyawati, A., \& Nugraheny, E. (2010). Midwifery care of the delivery mother. Jakarta: Salemba Medika. 112-118

Sumarah., Widyastuti, Y., \& Wiyati, N. (2009). Midwifery care of the delivery mother. Yogyakarta: Fitramaya.113-119

Walyani, E.S., \& Purwoastuti, E. (2016). Care of delivery and newborn. Yogyakarta: Pustaka Baru Press.91-98

World Health Organization. (2015). Mediacentre. Diakses pada tanggal 15 Maret 2017, dari http://who.int. 